\title{
Ecumenical movement for millennials: A generation connected but not yet united
}

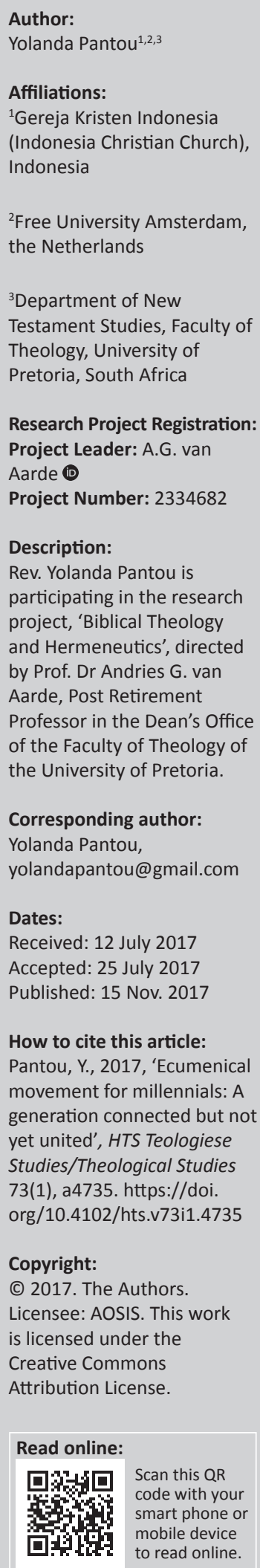

In this article the notion 'ecumenism' is defined as a connecting movement of reconciling diversity, and the focus is on young people, referred to as 'millennials' living in the presentday global village. It addresses the youth's interests or disinterests in the 'institutionalised' ecumenical movement. The following aspects are reflected upon: how ecumenism speaks to the youth; how ecumenism does not speak to the youth; and how to make ecumenism great again for the youth. It discusses young people's perspectives on the world with regard to religion and tradition, sources of authority, issues of segregation and discrimination, 'nomadic' and a mentality which causes that one cannot expect them to stay in one church from baptism until death. The article reflects on the youth's disposition to human realities concerning aspects such as the ecological crisis, global inequality, religious fundamentalism, violence and oppression, and the lack of a sense of belonging. The article concludes with some initiatives of the World Council of Churches to which young people can make a contribution.

\section{Ecumenism as connecting}

If ecumenism is about connecting despite distance and uniting despite differences, then it speaks the language of young people today. Often referred to as millennials, ${ }^{1}$ young people are more connected than previous generations have ever been. Although unity is not fully attained, the global village in which they live presents many more possibilities for achieving that ideal which was previously the case.

Therefore, to discuss ecumenism without considering the opinions and the role of the youth and the influence of religion on their lives will not do justice to our endeavours to journey together as the Church. Currently, the youth are not sufficiently present in the ecumenical movement. This may be because they are not given much opportunity to be involved. It may also be because they are not interested in the ecumenical movement or the institutional and traditional religions it represents.

In this article, I point to some parallels between ecumenism and youth as the connected generation. The aim is to explore factors that can contribute to making ecumenism relevant to young people.

\section{How ecumenism speaks to the youth}

In the 1990s there was a trend that parents, when naming their newborn babies, created an email account for them so that they could have an email account that reflected their birth year. This trend may have been abandoned or replaced with a social media account, but these children (who are now our youth) were 'born to be connected' before they even knew about it. Now as young adults, they are living hyper-connected lives: virtually everything they do, see and think is announced to their contacts in real time. This lifestyle is not limited to the youth.

Millennials are inundated with information and have an abundance of knowledge sources at their fingertips. They can become self-taught experts in no time at all: from cooking a complicated dish to building a house, from constructing an electricity generator out of waste material to assembling a bomb. They are so well informed and connected that they can travel the world with little other than their smart phones, they have friends all over the world whom

1.Although descriptions of this generation differ, it is safe to say that the millennials are those who were born after 1980 and have reached young adulthood in the 21st century.

Note: This article represents a reworked version of a paper presented at Youth Day 16 June 2017 in the Senate Hall of the University of Pretoria as part of the Commission of Faith and Order of the World Council of Churches collaborating with the Faculty of Theology of the University of Pretoria during its centennial celebration in 2017. 
they have never met, and sadly they can also learn to hate those whom they have never known in person, because their opinions are shaped by global media and social media commentators.

Their context is a global village where an Indonesian's favourite food can be lasagne, a Mexican's sushi and where virtually every home contains some things made in China. On the one hand, they are exposed to a plurality of cultures and norms, and on the other hand they are drawn into the uniformity of current trends and the socio-economic standards they feel they have to live up to in order to have 'made it' in this world.

Although they may not know the philosophy by name or intentionally associate with it, young people of today tend to exhibit a 'postmodern' mentality, acknowledging that there are different truths. Heroes, for example, have a dark side and villains exhibit some goodness. Although this mentality can generally be regarded as good news for humanity, it also causes young people to question the relevance of church, tradition and (inherited) religion for their lives - which brings us to the challenges we face.

\section{How ecumenism does not speak to the youth}

The following religious settings can be distinguished: secular countries, non-Christian countries and Christian countries that suffer from poverty and violence. North America, South Africa and some other predominantly Christian countries that are socio-economically above the poverty level are exceptions to this classification. In none of these categories church denominations are a main concern of the youth. For example, young people from Muslim or ultra-secular countries may not have a problem befriending a young Christian who has a different belief system. For those who live in Christian countries and suffer from poverty or oppression, the unity of the body of Christ may not be an existential experience. Young Christians from the global south inherited a divided church from missionaries and colonising powers.

If anything, they may be more drawn to religious fundamentalism and ultra-nationalism. Separatism is for them more about religious identity, worldview and national or racial identity than about church denomination or tradition. Such young people can either be opponents or be supporters of radicalism. In many cases, it is young people who are the perpetrators of racial violence, religious radicalism or hate-speech with regard to others' worldviews.

Although these constitute a smaller percentage of young people than the other categories mentioned, they are enough to make the ecumenical movement to be put in a box wherein they do not want to be confined. However, seen from another perspective, ecumenism is already being practised by the youth, even though it is not called ecumenism or is formally institutionalised.

\section{How to make ecumenism great again for the youth}

With the above question the intention is not to call to mind the infamous slogan we hear so often these days, but rather to acknowledge the role of young people in the ecumenical movement in the past, similar to the role they have played in many places in the world in bringing about change for the better. Therefore, it should be taken seriously if the movement previously driven by the youth is now no longer of interest to them.

There are ways to get their attention and engage them deeply in our movement for the visible unity of the church. Firstly, we should see things also from their perspective rather than forcing ours onto them. To learn more about their perspective not only has the aim to get a foot in the door to dialogue, but to let their perspective shape the ecumenical movement. Secondly, we should speak from the real challenges of the world, the global reality that needs an immediate and theological response. And last but not least, the only way to convey the importance of ecumenism is to walk the talk.

\section{Perspective}

How the youth see the world will differ from our perspective (in communal not individual terms). They also attach a different value and degree of importance to it. We can explore their perspectives along the lines of the following themes.

\section{Religion and tradition}

Globally it is becoming increasingly difficult to involve young people in church services and activities. Rather than chalk it up to a shift in how they view religion, I think it is because of changed parenting methods, increased democratic decisionmaking in family life and the society changing rapidly.

However, despite the global decrease in the church attendance of young people, their attitude towards religion is not homogenous. For some, both religion and tradition are obsolete and can disappear without it being a great loss. For others, religion (not so much tradition) is fragile yet valuable and should therefore be vigorously defended. Yet others regard religion and tradition as optional identities that can be freely adopted should they choose to do so. Some consider themselves as 'cultural Christians', whereas others dedicate themselves to living faithfully according to the beliefs and in the denominations in which they were brought up. This last category is probably of most interest to the ecumenical movement, though we cannot write off the others completely. They might have a change of heart along the way.

\section{Sources of authority}

In the past, and especially in the global south, sources of authority were parents, teachers, church leaders and the Bible. The youth of today choose to whom they are willing to listen. This varies from a Holy Book to popular culture, from a university lecturer to a Hollywood celebrity. One thing that has not changed much is the role of peers in affirming their 
choice. This is why, for young people, the church and other established institutions are one of many options, or are up for discussion. The existence of a variety of denominations is all the more reason for them to doubt the authority of a church.

\section{Issues of segregation and discrimination}

While for the older generation these may still be an issue, the youth have a different perspective and take a different direction. Issues of segregation and discrimination such as racism, classism, elitism and gender bias are seen by them as a thing of the past. People are no longer judged on account of the identity with which they were born or their upbringing. This perspective can be of great advantage in the ecumenical movement as a way of combatting racism and other forms of discrimination. This will have to be stated clearly and soon; otherwise the ecumenical movement will be seen as stuck in churches' old ways of segregating people.

\section{Moral issues}

While churches are struggling with the so-called 'moral issues' such as human sexuality, the youth in many parts of the world have no problem with it. Of course, there are still those who judge others on account of their sexual orientation, but the trend is that this kind of attitude is diminishing among young people. For them, morality is about taking action that has direct social impact, rather than about a personal way of life. Corruption, violence, disrespect for human and animal rights and injustice are, for instance, moral issues to which young people respond with a passionate plea for change.

\section{Mentality}

Although it is impossible to generalise about a generation that includes a wide range of people from different places and contexts, there are some indications of a common mentality. They are generally sceptical of authority and institutions. Their sense of entitlement derives from an upbringing where they were rewarded just for participation. They tend to choose work satisfaction over a higher salary and experience over material belongings. Some prefer travel to being tied down by a mortgage. Others choose to live minimalistically and aim to be eco-friendly rather than owning a big house they have to spend much time and money maintaining. Some have a nomadic lifestyle. They are ready to move even after having settled down. The world has become digitalised. They can work from anywhere on the earth. With such a penchant for mobility, they cannot be expected to stay in one church from baptism until death.

\section{Human realities \\ Environmental crisis}

Our earth is deteriorating, which we cannot deny. It affects all people, young and old. Young people have been raised with a greater awareness and therefore tend to care more. They are the ones who will have to live with the consequences. In the battle between economic gain and ecological conservation, ecumenism provides an alternative: to share more justly with one another and to respect the earth as God's creation, not as the belonging of human beings and their governments. If we focus our energy on doing theology in reconciliation with the earth and putting it into action, this can be a way in which ecumenism speaks the same language as young people.

\section{Global inequality}

Along with their different perspectives on segregation, the young people of today are also more aware than previous generations of their privileges or disadvantages. Inequality is not regarded as a given to be accepted, but rather as a challenge to be defeated.

\section{Religious fundamentalism}

The world is more connected now than ever before, but at the same time there are also sharper divisions than ever before. One reason is the growth of religious fundamentalism. Young people are drawn to religious fundamentalism (and other kinds of fanaticism), either as adversaries or as perpetrators. If engagement with young people is to be pursued, this matter will have to be discussed and peaceful action should be taken. The ecumenical movement should be the living antithesis of religious fundamentalism or any form of fanaticism.

\section{Violence and oppression}

In the face of violence and oppression, the young people are our hope. They are our encouragement not to give in, nor to give up. However, violence and oppression can feel like a giant web from which there is no escape. Therefore, the ecumenical idea of a visible unity can provide appealing language for young people to go out with their idealism and make the world a better and more peaceful place.

\section{Emptiness and the lack of a sense of belonging}

As our society shifts from a more communal to a more individualistic lifestyle, this can lead to a crippling sense of loneliness and emptiness. A reason can be that we have more alone time to reflect on our failures. It can be because we have fewer people with whom to share our successes. Human beings need a sense of belonging. When even religion has become relegated to the personal and private life, the vision of a community that stays, prays, lives and walks together despite differences can become a model for true connection and unity.

\section{Action}

In this section, I connect some positive initiatives of the World Council of Churches (WCC) with what the young people can bring to the table.

\section{Pilgrimage of justice and peace}

For a nomad generation, the term 'pilgrimage' can be appealing. Pilgrims learn, unlearn and encounter others where they are. Others challenge pilgrims to look at the 
world from their perspective. The ideal of justice and peace can also provide an answer to young people's external and internal restlessness.

\section{Spirituality and care for the earth}

Although the doctrinal and theological discussion of the Faith and Order Commission is central to developing responsible programmes to walk together, the programmes such as the Week of Prayer for Christian Unity and those related to water justice are the ones that may specifically speak about the needs of young people.

\section{Community building}

Many of those involved in the work of the WCC began as stewards when they were young. Being a steward is not only about assisting at events. It is about experiencing the life of an ecumenical community. The 'ecumenical buddy' system, initiated by the Echos Commission (European Civil Protection and Humanitarian Aid Operations), ${ }^{2}$ is one of the ways in which new people are welcomed into the ecumenical community. New persons are paired with experienced ones who can pass on their knowledge and experience.

\section{Benchmarking}

What I have discussed so far is still more about what we do for the youth than about involving them in ecumenical work. With regard to another ecumenical body which constitutes a reference point for the WCC, namely the World Communion of Reformed Churches (WCRC), much is to learn. The fact that youth interest in ecumenism and opportunities to participate have in the past not been sufficiently prompted the WCRC, at its 2017 general assembly in Leipzig, they have to take some decisive steps to rectify the matter. Not only did a host of young people work at the conference, there was also a pre-council meeting for youth, funding was made available for delegates under the age of 30 which encouraged churches to send young delegates and one of the vice-president positions is now filled by a young person. Regarding regional representation in the Executive, not only race,

2.http://ec.eduropa.eu/echo/ gender and language but also age was taken into account when striving to find a balanced representation. This past meeting of the WCRC has shown a strong focus and decisive action with regard to youth participation.

I know that the Faith and Order Commission of the WCC understands very well the importance of involving young people in the ecumenical journey and its movement toward becoming the one Church of Christ. The perspective I offer is not about bringing them into the movement, because they may not be interested at all at this point in time. It is rather about us making ourselves compatible with them, their situation and challenges so that we can be better partners for one another on our journey together. Only if we humble ourselves can they begin to consider us a relevant movement for this present time and for future life.

\section{Acknowledgements Competing interests}

The author declares that she has no financial or personal relationships which may have inappropriately influenced her in writing this article.

\section{Recommended literature}

Dreyer, Y., 2004, 'A public practical theological theory for religious education of secularised youth', HTS Theological Studies 60(3), 919-945.

Hamilton, K.A., 2011, 'People of paradox', Journal of Ecumenical Studies 64(3), 365-367.

Holli, J.L., 2010, 'Ecumenism: Moving toward a multi-faceted global conversation mission and unity: Ecclesiology and mission', in K. Sandwig (ed.), Edinburgh 2010: Youth perspectives, pp. 87-93, William Carey International University Press, Pasadena, CA.

Nayak, A., [2003] 2016, Race, place and globalization: Youth cultures in a changing world, Bloomsbury Academic, London.

Osmer, R.R. \& Dean, K.C. (eds.), 2007, Youth, religion and globalization: New research in Practical Theology, with preface by F. Schweitzer, LitVerlag, Berlin. (International Practical Theology).

Rattansi, A. \& Phoenix, A., 2005, 'Rethinking youth identities: Modernist and postmodernist frameworks', Identity. An International Journal of Theory and Research 5(2), 97-123.

Ziebertz, H.-G. \& Kay, W.K. (eds.), 2009a, Youth in Europe I: An international empirical study about life perspectives, with preface by L. Nistelrooij, 2nd edn., LitVerlag, Berlin. (International Practical Theology).

Ziebertz, H.-G. \& Kay, W.K. (eds.), 2009b, Youth in Europe II: An international empirical Study about religiosity, with preface by J. Bozanic, LitVerlag, Berlin. (International Practical Theology).

Ziebertz, H.-G., Kay, W.K. \& Riegel, U. (eds.), 2009, Youth in Europe III: An international empirical study about the impact of religion on life orientation, with preface by $\mathrm{S}$. E. Rogobete, LitVerlag, Berlin. (International Practical Theology). 